\title{
Corticotropin-Releasing Factor Receptor Antagonism within the Dorsal Raphe Nucleus Reduces Social Anxiety-Like Behavior after Early-Life Social Isolation
}

\author{
Jodi Lukkes, ${ }^{1,2}$ Shawn Vuong, ${ }^{1}$ Jamie Scholl, ${ }^{1}$ Harvey Oliver, ${ }^{1}$ and Gina Forster ${ }^{1}$ \\ ${ }^{1}$ Neuroscience Group, Division of Basic Biomedical Sciences, Sanford School of Medicine, University of South Dakota, Vermillion, South Dakota 57069, and \\ ${ }^{2}$ Department of Integrative Physiology, University of Colorado, Boulder, Colorado 80309
}

\begin{abstract}
Social isolation of rats during the early part of development increases social anxiety-like behavior in adulthood. Furthermore, early-life social isolation increases the levels of corticotropin-releasing factor (CRF) receptors in the serotonergic dorsal raphe nucleus ( $\mathrm{dRN}$ ) of adult rats. Interactions between serotonin and CRF systems are thought to mediate anxiety behavior. Therefore, we investigated the effects of CRF receptor antagonism within the dRN on social anxiety-like behavior after early-life social isolation. Male rats were reared in isolation or in groups from weaning until midadolescence, and rehoused in groups and allowed to develop into adulthood. Adult rats underwent surgery to implant a drug cannula into the dRN. After recovery from surgery and acclimation to the testing arena, rats were infused with vehicle or the CRF receptor antagonist D-Phe-CRF $\mathrm{C}_{(12-41)}(50 \mathrm{or} 500 \mathrm{ng})$ into the $\mathrm{dRN}$ before a social interaction test. Isolation-reared rats pretreated with vehicle exhibited increased social anxiety-like behavior compared with rats reared in groups. Pretreatment of the $\mathrm{dRN}$ with $\mathrm{D}-\mathrm{Phe}-\mathrm{CRF}_{(12-41)}$ significantly reduced social anxietylike behaviors exhibited by isolation-reared rats. Overall, this study shows that early-life social stress results in heightened social anxiety-like behavior, which is reversed by CRF antagonism within the dRN. These data suggest that CRF receptor antagonists could provide a potential treatment of stress-related social anxiety.
\end{abstract}

\section{Introduction}

Early-life stress is associated with the development of neuropsychiatric disorders in adulthood (Nemeroff, 2004). Isolation of rats from social counterparts during a critical period of development models chronic early-life stress and causes alterations to anxiety-like behavior that persist into adulthood, even after resocialization (Hall, 1998). Specifically, isolation of rats from preadolescence to midadolescence increases subsequent anxiety-like and fear behavior of midadolescent and adult rats within a social interaction test (van den Berg et al., 1999; Lukkes et al., 2009a).

Corticotropin-releasing factor (CRF) is an important mediator of anxiety-like and stress behavior (Bale, 2005). Central administration of CRF or CRF receptor agonists increases anxiogenic behavior in the open field (Takahashi et al., 1989), elevated plus maze (Pelleymounter et al., 2002), and social interaction test (Spiga et al., 2006). Furthermore, ventricular infusion of CRF receptor antagonists produces anxiolytic effects in these behavioral tests (Spina et al., 2000). Increased serotonergic activity also modulates anxiety-like behavior (Lowry et al., 2005). For example, pretreatment of the basolateral amygdala with a serotonin

Received Feb. 19, 2009; revised June 5, 2009; accepted June 28, 2009.

This work was supported by National Institutes of Health (NIH) Grants R01 DA019921 and Centers of Biomedical Research Excellence P20 RR15567, but is solely the responsibility of the authors and does not necessarily represent the official views of NIH. We thank Dr. Michael Watt for helpful suggestions regarding these experiments.

Correspondence should be addressed to Dr. Gina Forster, Division of Basic Biomedical Sciences, Sanford School of Medicine, University of South Dakota, 414 East Clark Street, Vermillion, SD 57069-2390. E-mail: gforster@usd.edu. D0I:10.1523/JNEUROSCI.0854-09.2009

Copyright $\odot 2009$ Society for Neuroscience $\quad$ 0270-6474/09/299955-06\$15.00/0 receptor agonist increases anxiety-like behavior in a social interaction test, whereas serotonin receptor antagonists have anxiolytic effects in this anxiety test (Gonzalez et al., 1996). In addition, CRF modulates limbic serotonin release via CRF receptor activation in the dorsal raphe nucleus (dRN) (Price and Lucki, 2001; Forster et al., 2006). Activation of $\mathrm{CRF}_{2}$ receptors in the dRN increase serotonergic neuronal activity (Pernar et al., 2004) and increases serotonin release in areas of the limbic system, such as the nucleus accumbens and amygdala (Amat et al., 2004; Lukkes et al., 2008). Interestingly, adult rats that were reared in isolation during early life show prolonged CRF-mediated serotonin release in the nucleus accumbens and increased $\mathrm{CRF}_{2}$ receptors in the dRN (Lukkes et al., 2009b).

Given the important role of CRF and serotonin in modulating anxiety-like behavior, elevated social anxiety-like behaviors observed in isolates could result from increased CRF receptor activation in the $\mathrm{dRN}$. Certainly, CRF receptor antagonism within the $\mathrm{dRN}$ reduces the social deficits associated with social defeat of adult hamsters (Cooper and Huhman, 2007). Therefore, this study examined whether CRF receptor antagonism within the $\mathrm{dRN}$ before a social interaction test could reverse the anxiogenic profile of adult rats reared in isolation.

\section{Materials and Methods}

Animals and social isolation protocol. One hundred and twenty-two male Sprague Dawley rats (University of South Dakota Laboratory Animal Services, Vermillion, SD) were obtained at postnatal day 21 (P21) (day of weaning) and housed at a constant room temperature $\left(22^{\circ} \mathrm{C}, 60 \%\right.$ rela- 


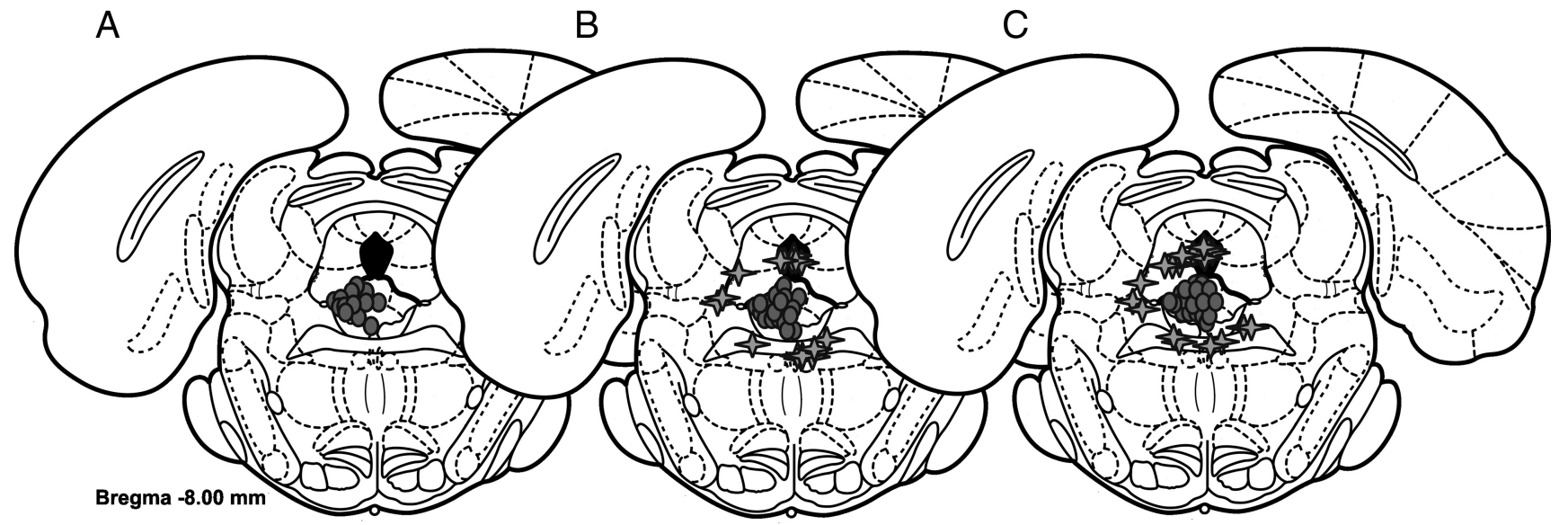

Figure 1. Cannula placements in the dRN. Schematic representations of drug infusion cannulae placements in the dRN (gray dots) or outside the dRN (gray stars) for control pair-housed (A), group-reared $(\boldsymbol{B})$, and isolation-reared $(\boldsymbol{C})$ rats. Figures were adapted from Paxinos and Watson (1997).

tive humidity) with a reverse $12 \mathrm{~h}$ light/dark cycle (lights off at 10:00 A.M.). Food and water were available ad libitum. The following procedures were approved by the University of South Dakota Institutional Animal Care and Use Committee and were performed in accordance with the National Institutes of Health Guide for the Care and Use of Laboratory Animals.

The current study used an early-life social isolation procedure that has been previously shown to increase CRF-mediated serotonin release, CRF receptor levels in the $\mathrm{dRN}$, and social anxiety-like behavior (Lukkes et al., 2009a,b). On P21, male rats were housed either individually or in groups of three for a period of 3 weeks during preadolescent to midadolescent development (Andersen, 2003). After 3 weeks of isolation or group rearing, all rats were weighed and housed in groups of three (within the same treatment groups) for a resocialization period of 2 weeks (Lukkes et al., 2009a,b). At the end of the 5 week isolation/resocialization procedure, rats reached early adulthood (P56) and underwent stereotaxic surgery. A separate cohort of rats was used for control experiments to determine the effects of CRF receptor antagonism on locomotion in the absence of social interaction. Control rats were weaned at P21, reared in pairs, and underwent stereotaxic surgery at P56.

Stereotaxic surgery. Rats were anesthetized with a ketamine $(80$ $\mathrm{mg} / \mathrm{kg}$, i.p.; Met-Vet)/xylazine (6 mg/kg, i.p.; Rx Veterinary Products) mixture and placed in a stereotaxic frame (David Kopf Instruments) with the incisor bar set at $-3.3 \mathrm{~mm}$. A 22 gauge guide cannula (5 mm in length; Plastics One) was stereotaxically implanted $1 \mathrm{~mm}$ above the dRN (anteroposterior, $-7.8 \mathrm{~mm}$ from bregma; mediolateral, -2.6 from midline) (Paxinos and Watson, 1997) at a $23^{\circ}$ angle to avoid the cerebral aqueduct (Forster et al., 2006). Rats were administered the analgesic ketoprofen $(5 \mathrm{mg} / \mathrm{kg}$, i.m.; Fort Dodge Animal Health) at the conclusion of each surgery. All rats were allowed $2 \mathrm{~d}$ of recovery from surgery before acclimation to testing procedures.

Acclimation to the infusion procedure and to the testing arena. Acclimation procedures and behavioral testing were conducted during the dark phase of the light cycle from 11:00 A.M. to 5:00 P.M. Two days after surgery, all rats were acclimated to the infusion procedure and the testing arena over 3 consecutive days. The rat was gently restrained and a 30 gauge stainless-steel infusion cannula ( $1 \mathrm{~mm}$ longer than the guide) was inserted into the guide cannula. Artificial CSF (aCSF) (0.1005 g of KCl, $4.295 \mathrm{~g}$ of NaCl, $0.062 \mathrm{~g}$ of $\mathrm{NaH}_{2} \mathrm{PO}_{4}, 0.0995$ $\mathrm{g}$ of $\mathrm{Na}_{2} \mathrm{HPO}_{4}, 0.1015 \mathrm{~g}$ of $\mathrm{MgCl}_{2}$, and $0.088 \mathrm{~g}$ of $\mathrm{CaCl}_{2}$ in $500 \mathrm{ml} ; \mathrm{pH}$ 7.4) was infused into the dRN $(0.5 \mu \mathrm{l})$ over 1 min using a microinfusion pump (Stoelting). The cannula was left in place for an additional minute to allow for complete diffusion. On removal of the cannula, rats were returned to their home cages, and $20 \mathrm{~min}$ later, rats were placed into the testing arena for $30 \mathrm{~min}$. The testing arena $(97.8 \times$ $70.17 \times 31.8 \mathrm{~cm}$ ) was within a dark experimental room illuminated by red light. Total distance moved (in centimeters) was recorded for
30 min over the $3 \mathrm{~d}$ acclimation period (Ethovision 3.1; Noldus Information Technology).

Social interaction test. After the $3 \mathrm{~d}$ acclimation period, both groupand isolation-reared rats were infused with aCSF (vehicle) or the $\mathrm{CRF}_{1 / 2}$ receptor antagonist D-Phe-CRF ${ }_{(12-41)}\left[\left[\mathrm{D}-\mathrm{Phe}^{12}, \mathrm{Nle}^{21,38}, \alpha-\right.\right.$ Me-Leu $\left.{ }^{37}\right]-\mathrm{CRF}_{(12-41)}$ (human, rat); 50 or $500 \mathrm{ng}$ in $0.5 \mu \mathrm{l}$ of aCSF; Bachem Americas] into the dRN $20 \mathrm{~min}$ before the $30 \mathrm{~min}$ social interaction test. The doses (50 or $500 \mathrm{ng}$ ) of D-Phe-CRF $\mathrm{C}_{(2-41)}$ used were based on those shown to reduce anxiety-like behavior after intracranial infusion (Erb and Stewart, 1999; Cooper and Huhman, 2007), and the volume $(0.5 \mu \mathrm{l})$ infused into the $\mathrm{dRN}$ does not have nonspecific effects by diffusion into areas surrounding the dRN (Forster et al., 2006; Lukkes et al., 2008).

The social interaction test consisted of placing an unfamiliar pairhoused male rat, size matched with the experimental rat $( \pm 20 \mathrm{~g})$, at one end of the arena and a group- or isolation-reared rat in the other end of the arena. Behaviors scored were the latency of the group- or isolation-reared rat to first approach the unfamiliar conspecific (in seconds), the total duration (in seconds) of social contacts (sniffing, chasing, crawling over, or grooming the unfamiliar conspecific), and the total duration of freezing behavior (in seconds) for group- and isolation-reared rats (Spiga et al., 2006; Lukkes et al., 2009a). As for our previous experiments (Lukkes et al., 2009a), aggressive behavior between the experimental and unfamiliar conspecific was not observed. Behavior from all testing sessions was scored by one observer blind to treatment (J.L.) using Observer XT (Noldus Information Technology).

Locomotion test. Control pair-housed rats were infused with aCSF or D-Phe-CRF ${ }_{(12-41)}(50$ or $500 \mathrm{ng}$ ) into the dRN, 20 min before placement in the testing arena for $30 \mathrm{~min}$. These rats were not exposed to the social interaction test. Instead, to determine whether D-Phe-CRF ${ }_{(12-41)}$ had any nonspecific effects on locomotion, total distance moved (in centimeters) was recorded by Ethovision 3.1 and divided into $5 \mathrm{~min}$ time bins.

Histology. At the conclusion of each behavioral experiment, rats were administered a lethal dose of Fatal-plus ( $0.5 \mathrm{ml}$, i.p.; Vortech). Brains were removed and fixed in $10 \%$ formalin. Sections $(60 \mu \mathrm{m})$ were cut at $-12^{\circ} \mathrm{C}$, and sections were analyzed under a light microscope by two experimenters blind to treatment for the location of drug infusion cannulae.

Data analysis. Significance levels for all statistical tests were set at $p \leq$ 0.05 (SigmaStat, version 2.03; SPSS). A Grubb's outlier test was performed before all ANOVAs as previously described (Lowry et al., 2001). The effect of rearing treatment on locomotion over the $3 \mathrm{~d}$ acclimation period or the effect of drug treatment on locomotion over time, were analyzed using separate two-way ANOVAs with one repeated measure (time). To further examine significant effects of time, one-way repeated-measure ANOVAs were also used, followed by Dunnett's post hoc analysis. For the social interaction test, the effects of rearing and drug treatment on anxiety-like measures were analyzed using sepa- 


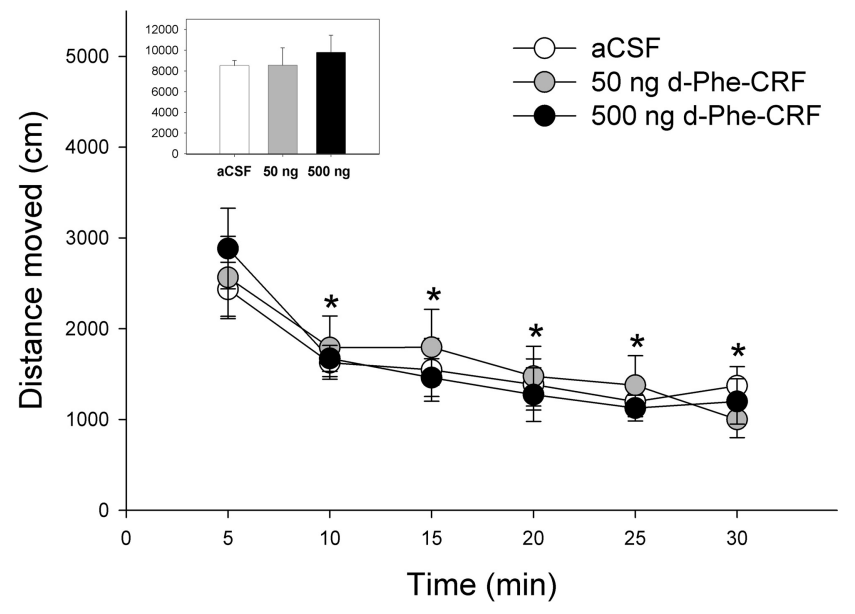

Figure 2. Infusion of D-Phe-CRF into the dRN does not differentially affect locomotion. All rats, regardless of dRN drug infusion, showed reduced levels of distance moved over the testing session. ${ }^{*} p<0.05$ compared with the first $5 \mathrm{~min}$ for all three drug treatments. The figure inset shows no significant difference in the total amount of distance moved between drug treatment groups. Error bars indicate SEM.

rate two-way ANOVAs, with significant effects further analyzed using Student-Newman-Keuls (SNK) post hoc comparisons.

\section{Results}

\section{Drug infusion cannulae placement}

Drug infusion cannulae were similarly located in the mid to posterior aspect of the $\mathrm{dRN}$ among control pair-housed $(n=21)$ (Fig. $1 A$ ), group-reared $(n=28)$ (Fig. $1 B$ ), and isolation-reared groups $(n=32)$ (Fig. $1 C$ ). Although infusions into the $\mathrm{dRN}$ were close to the cerebral aqueduct, cannulae were placed on a lateralto-medial angle to minimize diffusion into the cerebral aqueduct (Forster et al., 2006; Lukkes et al., 2008). Since the dRN is a medial structure, the spread of the infusion most likely encompassed the majority of the bilateral dRN. Cannulae placements adjacent to the dRN were used as anatomical controls (Fig. $1 B, C$ ) to illustrate that the effects of $0.5 \mu \mathrm{l}$ of D-Phe-CRF ${ }_{(12-41)}$ infused into the $\mathrm{dRN}$ were not attributable to spread to neighboring regions or into the ventricle (Forster et al., 2006; Lukkes et al., 2008).

\section{Infusion of D-Phe-CRF into the dRN does not differentially affect locomotion}

Total distance moved within the testing arena over the $3 \mathrm{~d}$ acclimation period before $\mathrm{dRN}$ drug treatment did not differ between pair-housed rats assigned to the different treatment groups $\left(F_{(2,32)}=0.112 ; p=0.894\right)$. Furthermore, infusion of aCSF $(n=7)$ or $\mathrm{D}-\mathrm{Phe}_{-\mathrm{CRF}_{(12-41)}}$ (50 or $500 \mathrm{ng} ; n=7$ /group) within the dRN did not differentially affect the total distance moved $\left(F_{(2,8)}=0.325 ; p=0.732\right)$ (Fig. 2, inset). To further analyze the effect of drug treatment on locomotion, distance moved was examined within 5 min time bins across the testing session (Fig. 2). A significant effect of time $\left(F_{(5,82)}=25.644 ; p<\right.$ $0.001)$, but not of drug treatment $\left(F_{(2,17)}=0.146 ; p=0.865\right)$, nor an interaction between drug treatment and time $\left(F_{(10,82)}=0.803\right.$; $p=0.626$ ) was observed for control pair-housed rats infused with aCSF or D-Phe-CRF ${ }_{(12-41)}$ (50 or $500 \mathrm{ng}$ ) into the dRN. Post hoc analysis revealed that a significant decline in the amount of distance moved over time was observed in all three groups when compared with the first 5 min (Dunnett's $p<0.05$ ) (Fig. 2).
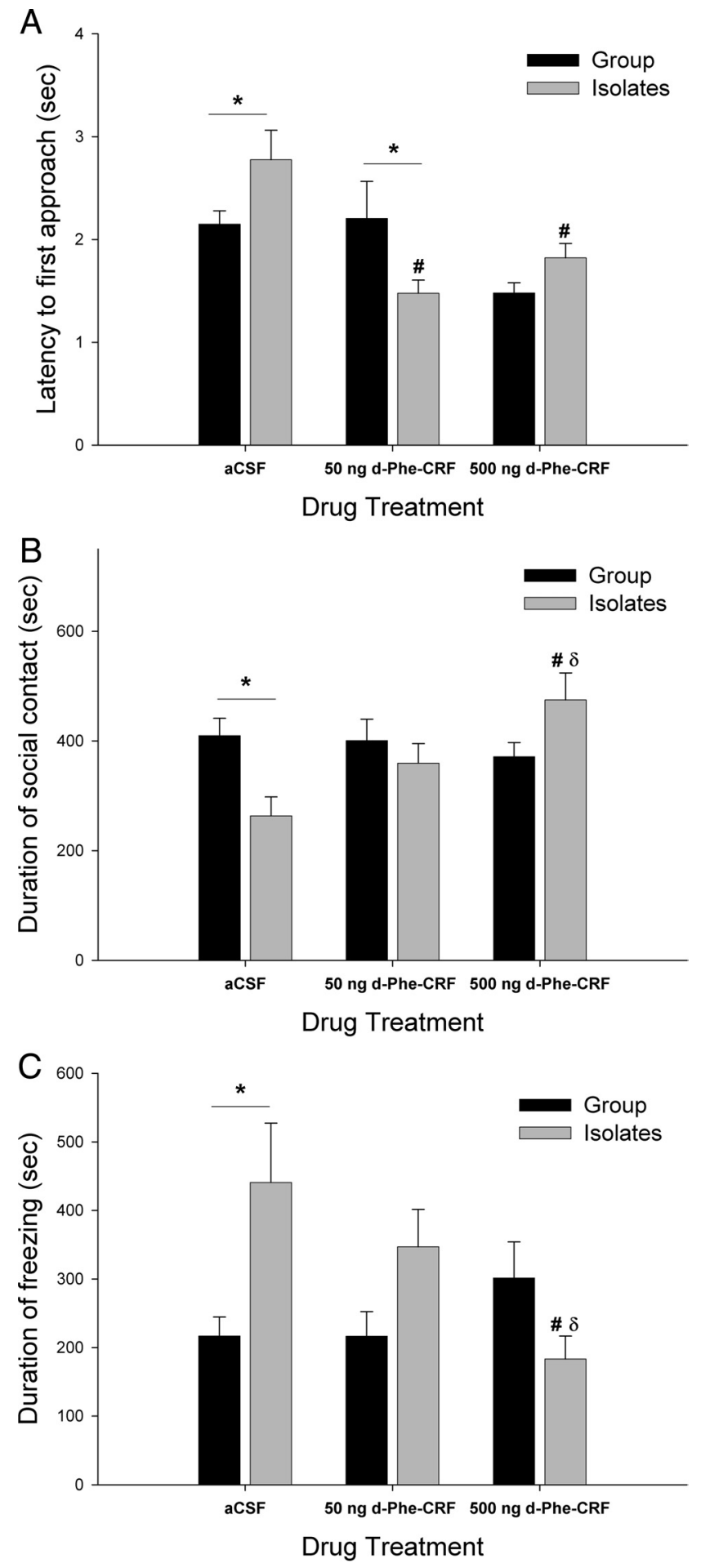

Figure 3. CRF receptor antagonism within the dRN reduced social anxiety-like behavior of isolates. $A$, Isolation-reared rats exhibited increased latency to approach an unfamiliar conspecific (aCSF treatment) compared with group-reared rats during a 30 min social interaction test, which was significantly decreased after pretreatment of the dRN with 50 and $500 \mathrm{ng}$ of $\mathrm{D}-$ PheCRF. $\boldsymbol{B}$, Isolation-reared rats exhibited decreased duration of social contact compared with group-reared rats, which was increased to group-reared rat levels by pretreatment of the dRN with D-Phe-CRF. C, Isolation-reared rats also showed increased duration of fear behavior compared with group-reared rats, which was reduced to group-reared rat levels by pretreatment of the dRN with D-Phe-CRF. ${ }^{*} p<0.05$ between group- and isolation-reared rats. ${ }^{\#} p<0.05$ compared with aCSF infusion. ${ }^{\delta} p<0.05$ compared with $50 \mathrm{ng}$ of $\mathrm{D}$-Phe-CRF infusion. Error bars indicate SEM. 
Table 1. Behavior of rats infused with vehicle or $\mathrm{D}-\mathrm{Phe}$-CRF adjacent to the $\mathrm{dRN}$

\begin{tabular}{|c|c|c|c|c|}
\hline Behavior & dRN treatment & Group reared & Isolation reared & ANOVA results \\
\hline \multirow[t]{3}{*}{ Latency to approach (s) } & $\mathrm{aCSF}$ & $1.91 \pm 0.45$ & $6.12 \pm 2.68$ & Rearing: $F_{(1,2)}=8.799 ; p=0.005$ \\
\hline & $50 \mathrm{ng}$ of $\mathrm{D}-\mathrm{Phe}-\mathrm{CRF}$ & $1.85 \pm 0.34$ & $3.52 \pm 0.48$ & Drug: $F_{(2,35)}=1.833 ; p=0.175$ \\
\hline & $500 \mathrm{ng}$ of $\mathrm{D}-\mathrm{Phe}-\mathrm{CRF}$ & $3.64 \pm 0.59$ & $5.25 \pm 1.45$ & Interaction: $F_{(2,35)}=0.063 ; p=0.939$ \\
\hline \multirow[t]{3}{*}{ Duration of social contact (s) } & $\mathrm{aCSF}$ & $446.91 \pm 60.48$ & $233.77 \pm 31.34$ & Rearing: $F_{(1,2)}=17.432 ; p<0.001$ \\
\hline & $50 \mathrm{ng}$ of $\mathrm{D}-\mathrm{Phe}-\mathrm{CRF}$ & $383.17 \pm 29.73$ & $278.65 \pm 34.33$ & Drug: $F_{(2,36)}=1.636 ; p=0.209$ \\
\hline & $500 \mathrm{ng}$ of $\mathrm{D}-\mathrm{Phe}-\mathrm{CRF}$ & $305.44 \pm 20.67$ & $180.14 \pm 55.79$ & Interaction: $F_{(2,36)}=2.549 ; p=0.092$ \\
\hline \multirow[t]{3}{*}{ Duration of freezing (s) } & $\mathrm{aCSF}$ & $199.94 \pm 32.92$ & $421.22 \pm 39.44$ & Rearing: $F_{(1,2)}=25.647 ; p<0.001$ \\
\hline & $50 \mathrm{ng}$ of D-Phe-CRF & $241.23 \pm 24.69$ & $445.62 \pm 55.86$ & Drug: $F_{(2,36)}=0.644 ; p=0.531$ \\
\hline & $500 \mathrm{ng}$ of $\mathrm{D}-\mathrm{Phe}-\mathrm{CRF}$ & $116.39 \pm 12.30$ & $432.92 \pm 149.07$ & Interaction: $F_{(2,36)}=0.406 ; p=0.669$ \\
\hline
\end{tabular}

Shown are mean \pm SEM $(n=3-10)$.

\section{CRF antagonism within the dRN decreases anxiety-like} behavior of isolation-reared rats in the social interaction test Locomotion over the $3 \mathrm{~d}$ acclimation period did not differ between group- $(n=28)$ and isolation-reared $(n=32)$ rats $\left(F_{(1,159)}=2.839 ; p=0.094\right)$. During the $30 \mathrm{~min}$ social interaction test, the latency to approach an unfamiliar conspecific was significantly altered by drug treatment $\left(F_{(2,45)}=6.558 ; p=0.003\right)$, and an interaction between drug treatment and the day of testing was apparent $\left(F_{(2,45)}=4.423 ; p=0.018\right)$, but an effect of rearing alone was not significant $\left(F_{(1,45)}=0.162 ; p=0.689\right)$. Isolationreared rats pretreated with vehicle $(n=11)$ exhibited a significant increase in the latency to approach an unfamiliar conspecific when compared with group-reared rats $(n=11)(\mathrm{SNK}, p<0.05)$ (Fig. 3A). However, pretreatment of the dRN with $50 \mathrm{ng}$ of D-Phe-CRF $\mathrm{C}_{(12-41)}$ significantly reduced the latency for isolationreared rats $(n=10)$ to approach an unfamiliar conspecific when compared $50 \mathrm{ng} \mathrm{D}-\mathrm{Phe}-\mathrm{CRF}_{(12-41)}$-pretreated group-reared rats $(n=10)$ and to vehicle-pretreated isolates (SNK, $p<0.05)$ (Fig. $3 A$ ). Furthermore, pretreatment of the dRN with $500 \mathrm{ng}$ of D-Phe-CRF (12-41) also reduced the latency for isolation-reared rats $(n=11)$ to approach an unfamiliar conspecific when compared with vehicle-pretreated isolates ( $\mathrm{SNK}, p<0.05$ ), resulting in isolates exhibiting similar latency to approach as $500 \mathrm{ng} \mathrm{D}-\mathrm{Phe}-$ $\mathrm{CRF}_{(12-41)}$-pretreated group-reared rats $(n=8)(\mathrm{SNK}, p>0.05)$ (Fig. $3 A$ ). In contrast, the latency to approach was not different among D-Phe-CRF $\mathrm{C}_{(12-41)}$ (50 or $500 \mathrm{ng}$ ) or vehicle-pretreated group-reared rats (Fig. $3 A$ ) (SNK, $p>0.05$ for all comparisons).

A significant interaction between rearing and drug treatment $\left(F_{(2,51)}=4.124 ; p=0.022\right)$ was observed for the total duration of social contacts, but there was no significant effect of rearing $\left(F_{(1,51)}=0.346 ; p=0.559\right)$ or drug treatment alone $\left(F_{(2,51)}=\right.$ $1.731 ; p=0.187)$. Isolation-reared rats pretreated with vehicle exhibited a significant decrease in the total duration of social contacts when compared with vehicle-treated group-reared rats $(\mathrm{SNK}, p<0.05$ ) (Fig. 3B). Pretreatment of the dRN with $500 \mathrm{ng}$ of D-Phe-CRF ${ }_{(12-41)}$ significantly increased the duration of social contact of isolation-reared rats when compared with $\mathrm{dRN}$ pretreatment of isolates with either vehicle or $50 \mathrm{ng}$ of $\mathrm{D}-\mathrm{Phe}-\mathrm{CRF}_{(12-41)}$ $(\mathrm{SNK}, p<0.05)$ (Fig. 3B). Furthermore, isolation- and group-reared rats showed similar levels of social contact when pretreated with 50 or $500 \mathrm{ng}$ of $\mathrm{D}-\mathrm{Phe}-\mathrm{CRF}_{(12-41)}$ (SNK comparisons between rearing groups at each dose $p>0.05$ ) (Fig. $3 B$ ). In contrast to isolationreared rats, there were no significant differences in the total duration of social contact between vehicle- and D-Phe-CRF ${ }_{(12-41)}(50$ or 500 ng)-pretreated group-reared rats (Fig. $3 B$ ) (SNK, $p>0.05$ for all comparisons).

A significant interaction between rearing and drug treatment $\left(F_{(2,52)}=6.045 ; p=0.004\right)$ was observed in the total duration of freezing behavior, but there was no significant effect of rearing $\left(F_{(1,52)}=3.549 ; p=0.065\right)$ or drug treatment alone $\left(F_{(2,52)}=\right.$
1.489; $p=0.235)$. Isolation-reared rats pretreated with vehicle exhibited significantly greater total duration of freezing behavior when compared with vehicle-treated group-reared rats (SNK, $p<0.05$ ) (Fig. 3C). Pretreatment of the dRN with $500 \mathrm{ng}$ of $\mathrm{D}-\mathrm{Phe}-\mathrm{CRF}_{(12-41)}$ significantly decreased the duration of freezing behavior of isolation-reared rats when compared with isolates pretreated with either vehicle or $50 \mathrm{ng}$ of $\mathrm{D}-\mathrm{Phe}-\mathrm{CRF}_{(12-41)}$ (SNK, $p<0.05$ ) (Fig. 3C). Furthermore, isolation- and group-reared rats showed similar levels of freezing behavior when pretreated with 50 or $500 \mathrm{ng}$ of D-Phe- $\mathrm{CRF}_{(12-41)}$ (SNK comparisons between rearing groups at each dose $p>0.05$ ) (Fig. 3C). In contrast to isolates, there were no significant differences in the duration of freezing behavior between group-reared rats pretreated with vehicle or D-Phe-CRF ${ }_{(12-41)}(50$ or $500 \mathrm{ng})($ Fig. $3 C)(\mathrm{SNK}, p>0.05$ for all comparisons). In contrast to the effects of $\mathrm{D}-\mathrm{Phe}-\mathrm{CRF}_{(12-41)}$ infused into the $\mathrm{dRN}$, infusion of $\mathrm{D}-\mathrm{Phe}-\mathrm{CRF}_{(12-41)}$ adjacent to the dRN (Fig. 1 B, C) did not reverse social anxiety-like behavior of isolation-reared rats as evidenced by a significant effect of rearing condition on the behavioral measures accompanied by a lack of drug effect (Table 1).

\section{Discussion}

The current study demonstrates that early-life stress results in elevated social anxiety-like behavior in adulthood. To illustrate, isolates infused with vehicle exhibited increased latency to first approach an unfamiliar conspecific, decreased duration of social contact, and increased duration of freezing behavior when compared with group-reared rats in the social interaction test. These behaviors exhibited by isolation-reared rats are indicative of heightened social anxiety (Spiga et al., 2006; Lukkes et al., 2009a).

The elevated social anxiety-like behavior observed in isolationreared rats was decreased by CRF receptor antagonism within the $\mathrm{dRN}$. Pretreatment of the $\mathrm{dRN}$ with both 50 and $500 \mathrm{ng}$ of D-Phe$\mathrm{CRF}_{(12-41)}$ decreased the latency to approach an unfamiliar conspecific in isolation-reared rats when compared with pretreatment of the $\mathrm{dRN}$ with vehicle. In addition, infusion of $500 \mathrm{ng}$ of D-Phe$\mathrm{CRF}_{(12-41)}$ within the $\mathrm{dRN}$ decreased the duration of freezing behavior and increased the duration of social contact in isolates when compared with infusion of vehicle. The effects of D-Phe$\mathrm{CRF}_{(12-41)}$ were specific to the $\mathrm{dRN}$, since infusions adjacent to the dRN did not reduce the heightened social anxiety behaviors exhibited by isolation-reared rats. Moreover, these anxiolytic effects could not be accounted for by D-Phe-CRF ${ }_{(12-41)}$ infusions producing nonspecific effects on activity such as increased locomotion within the testing arena. Although previous studies have shown that CRF receptor antagonists administered centrally or within the basolateral amygdala increase social contact during a social interaction test (Dunn and File, 1987; Gehlert et al., 2005), this is the first demonstration that CRF receptor antagonism within the dRN reverses social anxiety-like behavior after early- 
life stress. In line with the current study, 500 ng D-Phe-CRF ${ }_{(12-41)}$ pretreatment of $\mathrm{dRN}$ before social defeat increased the duration of social behavior and reduced submissive behavior of adult Syrian hamsters (Cooper and Huhman, 2007). Together, these data and the current study suggest that CRF receptors within the dRN are important components of the neural circuitry mediating social anxiety-like behavior.

In contrast to isolates, pretreatment of the $\mathrm{dRN}$ with $\mathrm{D}$-Phe$\mathrm{CRF}_{(12-41)}$ did not alter social or freezing behaviors of groupreared rats. Similar findings have been reported, in which CRF receptor antagonists, administered either systemically, intracerebroventricularly, or into the amygdala, reduce the anxiogenic effects of prestressors or CRF administration, but have little effect on the behavior of nonstressed animals (Heinrichs et al., 1992; Okuyama et al., 1999; Gehlert et al., 2005). This suggests that the ability of CRF receptor antagonists to reverse anxiety-like behaviors is dependent on previous stress experience. Specifically, the anxiolytic effects of CRF receptor antagonism for isolate rats in a social interaction test may be dependent on heightened CRFserotonin interactions in the dRN as previously observed after social isolation (Lukkes et al., 2009b). Furthermore, the results imply that CRF receptors in the $\mathrm{dRN}$ play little role in mediating social or anxiety behaviors in group-reared or unstressed rats.

Although D-Phe-CRF ${ }_{(12-41)}$ antagonizes both CRF receptor subtypes, it exhibits 2-10 times greater affinity for the $\mathrm{CRF}_{2}$ receptor compared with the $\mathrm{CRF}_{1}$ receptor (Perrin et al., 1999). In general, there is a high density of $\mathrm{CRF}_{2}$ receptors compared with $\mathrm{CRF}_{1}$ receptors within the dRN (Chalmers et al., 1995). Furthermore, isolation-reared rats have elevated levels of $\mathrm{CRF}_{2}$ receptors within the $\mathrm{dRN}$ compared with group-reared rats and show prolonged $\mathrm{CRF}_{2}$-mediated increases in serotonergic activity compared with group-reared rats (Lukkes et al., 2009a,b). The exact role of $\mathrm{CRF}_{1}$ or $\mathrm{CRF}_{2}$ receptors in mediating anxiogenic behavior remains controversial. Clark et al. (2007) show a more robust anxiogenic effect of chronic $\mathrm{CRF}_{1}$ receptor agonism in the dRN when compared with chronic $\mathrm{CRF}_{2}$ receptor agonism. Furthermore, $\mathrm{CRF}_{2}$ receptor knock-out mice display increased anxiety-like behavior in an elevated plus maze, suggesting that these receptors have an anxiolytic role (Bale, 2005). In contrast, $\mathrm{CRF}_{2}$ receptor antagonism via ventricular injection (Takahashi et al., 2001) or within the lateral septum (Henry et al., 2006) have an anxiolytic effect during anxiety tests, suggesting a role for $\mathrm{CRF}_{2}$ receptors in mediating anxiety-like behavior. To further elucidate the relationship between the CRF receptor subtypes and anxiety states, future studies should examine the role of dRN $\mathrm{CRF}_{1}$ and $\mathrm{CRF}_{2}$ receptor subtypes in mediating social anxietylike behavior after social isolation using antagonists specific for each receptor subtype.

In summary, the current data suggest CRF receptor antagonism within the $\mathrm{dRN}$ reduces social anxiety-like behavior in rats exposed to early-life stress. Both early-life stress and increased CRF levels have been implicated in several mood disorders, including anxiety and depression (Nemeroff, 2004). Therefore, CRF receptor antagonism represents a possible therapeutic treatment for stress-related affective disorders.

\section{References}

Amat J, Tamblyn JP, Paul ED, Bland ST, Amat P, Foster AC, Watkins LR, Maier SF (2004) Microinjection of urocortin 2 into the dorsal raphe nucleus activates serotonergic neurons and increases extracellular serotonin in the basolateral amygdala. Neuroscience 129:509-519.

Andersen SL (2003) Trajectories of brain development: point of vulnerability or window of opportunity? Neurosci Biobehav Rev 27:3-18.
Bale TL (2005) Sensitivity to stress: dysregulation of CRF pathways and disease development. Horm Behav 48:1-10.

Chalmers DT, Lovenberg TW, De Souza EB (1995) Localization of novel corticotropin releasing factor receptor (CRF2) mRNA expression to specific subcortical nuclei in rat brain: comparison with CRF1 receptor mRNA expression. J Neurosci 15:6340-6350.

Clark MS, McDevitt RA, Hoplight BJ, Neumaier JF (2007) Chronic low dose ovine corticotropin releasing factor or urocortin II into the rostral dorsal raphe alters exploratory behavior and serotonergic gene expression in specific subregions of the dorsal raphe. Neuroscience 146:1888-1905.

Cooper MA, Huhman KL (2007) Corticotropin-releasing factor receptors in the dorsal raphe nucleus modulate social behavior in Syrian hamsters. Psychopharmacology (Berl) 194:297-307.

Dunn AJ, File SE (1987) Corticotropin-releasing factor has an anxiogenic action in the social interaction test. Horm Behav 21:193-202.

Erb S, Stewart J (1999) A role for the bed nucleus of the stria terminalis, but not the amygdala, in the effects of corticotropin-releasing factor on stress-induced reinstatement of cocaine seeking. J Neurosci 19:RC35(1-6).

Forster GL, Feng N, Watt MJ, Korzan WJ, Mouw NJ, Summers CH, Renner KJ (2006) Corticotropin-releasing factor in the dorsal raphe elicits temporally distinct serotonergic responses in the limbic system in relation to fear behavior. Neuroscience 141:1047-1055.

Gehlert DR, Shekhar A, Morin SM, Hipskind PA, Zink C, Gackenheimer SL, Shaw J, Fitz SD, Sajdyk TJ (2005) Stress and central Urocortin increase anxiety-like behavior in the social interaction test via the CRF1 receptor. Eur J Pharmacol 509:145-153.

Gonzalez LE, Andrews N, File SE (1996) 5-HT1A and benzodiazepine receptors in the basolateral amygdala modulate anxiety in the social interaction test, but not in the elevated plus-maze. Brain Res 732:145-153.

Hall FS (1998) Social deprivation of neonatal, adolescent, and adult rats has distinct neurochemical and behavioral consequences. Crit Rev Neurobiol 12:129-162.

Heinrichs SC, Pich EM, Miczek KA, Britton KT, Koob GF (1992) Corticotropin releasing factor antagonist reduces emotionality in socially defeated rats via direct neurotropic action. Brain Res 581:190-197.

Henry B, Vale W, Markou A (2006) The effect of lateral septum corticotropin-releasing factor receptor 2 activation on anxiety is modulated by stress. J Neurosci 26:9142-9152.

Lowry CA, Burke KA, Renner KJ, Moore FL, Orchinik M (2001) Rapid changes in monoamine levels following administration of corticotropinreleasing factor or corticosterone are localized in the dorsomedial hypothalamus. Horm Behav 39:195-205.

Lowry CA, Johnson PL, Hay-Schmidt A, Mikkelsen J, Shekhar A (2005) Modulation of anxiety circuits by serotonergic systems. Stress 8:233-246.

Lukkes JL, Forster GL, Renner KJ, Summers CH (2008) Corticotropinreleasing factor 1 and 2 receptors in the dorsal raphe differentially affect serotonin release in the nucleus accumbens. Eur J Pharmacol 578:185-193.

Lukkes JL, Mokin MV, Scholl JL, Forster GL (2009a) Adult rats exposed to early-life social isolation exhibit increased anxiety and conditioned fear behavior, and altered hormonal stress responses. Horm Behav $55: 248-256$

Lukkes JL, Summers CH, Scholl JL, Renner KJ, Forster GL (2009b) Early life social isolation alters corticotropin-releasing factor responses in adult rats. Neuroscience 158:845-855.

Nemeroff CB (2004) Early-life adversity, CRF dysregulation, and vulnerability to mood and anxiety disorders. Psychopharmacol Bull 38 [Suppl 1]:14-20.

Okuyama S, Chaki S, Kawashima N, Suzuki Y, Ogawa S, Nakazato A, Kumagai T, Okubo T, Tomisawa K (1999) Receptor binding, behavioral, and electrophysiological profiles of nonpeptide corticotropin-releasing factor subtype 1 receptor antagonists CRA1000 and CRA1001. J Pharmacol Exp Ther 289:926-935.

Paxinos G, Watson C (1997) The rat brain in stereotaxic coordinates, Ed 3. New York: Academic.

Pelleymounter MA, Joppa M, Ling N, Foster AC (2002) Pharmacological evidence supporting a role for central corticotropin-releasing factor (2) receptors in behavioral, but not endocrine, response to environmental stress. J Pharmacol Exp Ther 302:145-152. 
Pernar L, Curtis AL, Vale WW, Rivier JE, Valentino RJ (2004) Selective activation of corticotropin-releasing factor-2 receptors on neurochemically identified neurons in the rat dorsal raphe nucleus reveals dual actions. J Neurosci 24:1305-1311.

Perrin MH, Sutton SW, Cervini LA, Rivier JE, Vale WW (1999) Comparison of an agonist, urocortin, and an antagonist, astressin, as radioligands for characterization of corticotropin-releasing factor receptors. J Pharmacol Exp Ther 288:729-734.

Price ML, Lucki I (2001) Regulation of serotonin release in the lateral septum and striatum by corticotropin-releasing factor. J Neurosci 21:2833-2841.

Spiga F, Lightman SL, Shekhar A, Lowry CA (2006) Injections of urocortin 1 into the basolateral amygdala induce anxiety-like behavior and c-Fos expression in brainstem serotonergic neurons. Neuroscience 138:1265-1276.
Spina MG, Basso AM, Zorilla EP, Heyser CJ, Rivier J, Vale W, Merlo-Pich E, Koob GF (2000) Behavioral effects of central administration of the novel CRF antagonist astressin in rats. Neuropsychopharmacology 22:230-239.

Takahashi LK, Kalin NH, Vanden Burgt JA, Sherman JE (1989) Corticotropin-releasing factor modulates defensive-withdrawal and exploratory behavior in rats. Behav Neurosci 103:648-654.

Takahashi LK, Ho SP, Livanov V, Graciani N, Arneric SP (2001) Antagonism of CRF(2) receptors produces anxiolytic behavior in animal models of anxiety. Brain Res 902:135-142.

van den Berg CL, Hol T, Van Ree JM, Spruijt BM, Everts H, Koolhaas JM (1999) Play is indispensable for an adequate development of coping with social challenges in the rat. Dev Psychobiol 34:129-138. 